\title{
GRASSLANDS NATIONAL PARK
}

GEORGE F. LEDINGHAM, Curator of the Vascular Plant Herbarium, University of Regina, Regina, Saskatchewan. S4S 0A2

The Saskatchewan Natural History Socie- for its efforts in publicizing the need to ty was recently recognized by Parks Canada preserve an area of prairie grassland. The

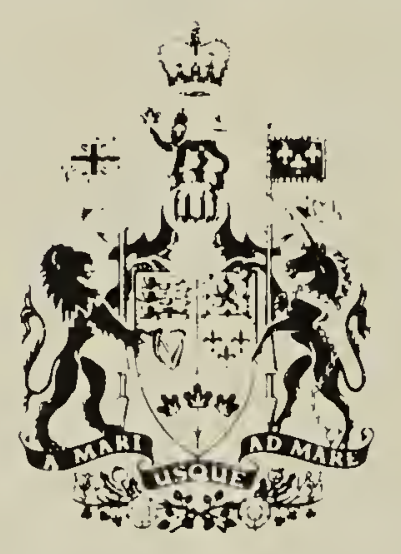

\section{National Heritage Award}

\author{
Presented by Parks Canada \\ On behalf of the Canadian people to
}

\section{Saskatchewan Natural History Society}

To record our thanks for the exceptional work and effort that contributed greatly to the establishment of Grasslands

National Park.

Thank you.

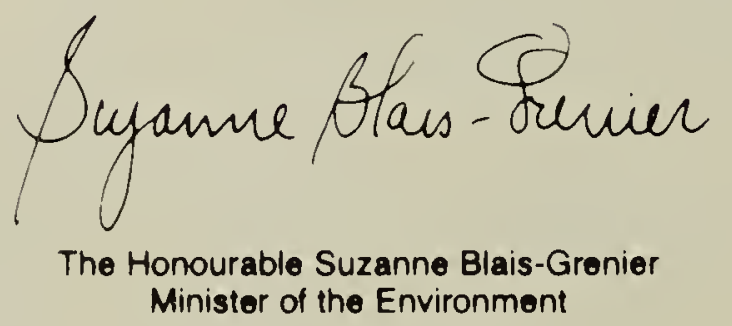

Canadä 
handsomely framed National Heritage Award was presented to representatives of the Society at a noon luncheon in the historic Railway Committee Room on Parliament Hill, 18 February 1985.

The heritage award to the Saskatchewan Natural History Society was received by Robert Coupland and George Ledingham. The former was long-time head of the Department of Plant Ecology in the University of Saskatchewan and is an internationally respected grassland ecologist. The latter is a founding member of the Society who for many years was chairman of the Society's grasslands park committee. Both had acted on a committee formed to promote the preservation of native grasslands. Both had acted as guides on the International Botanical Congress grasslands tour through Alberta and Saskatchewan in 1959.

Six awards in all were presented by Dr. Suzanne Blais-Grenier, Minister of the Environment, who noted that from one small Banff National Park established in 1885 there are now national parks in every province and territory and also hundreds of historic sites. The Minister praised the many volunteers who over the years had done so much to increase awareness of the importance of natural and cultural heritage during the first one hundred years of Parks Canada. She promised that more would be accomplished in the second century, by "inter-governmental as well as public/private participation."

The Saskatchewan Natural History Society first discussed the possibility of the formation of a national grasslands park in 1957 when the guest speaker at its annual meeting stated that Parks Canada wanted to preserve each kind of habitat and that the first priority of Parks Canada was preservation, not recreation. For some years the Society attempted to persuade the Province of Saskatchewan to set up one or more grassland preserves. Finally in 1963 it passed the resolution requesting the provincial and federal governments to establish a $\mathrm{Na}$ tional Park in the grasslands.
The idea was not new. Catlin in 1832 had proposed a large reserve to preserve bison and Indians! Later, when the antelope were close to extinction, three small grassland National Parks had been established but these disappeared when antelope populations recovered. The Society's proposal, however, differed from previous proposals which had been aimed at protection of one of two specific species. The aim of the Society was to preserve the whole complexity and beauty of a significant amount of Canadian prairie. To make this aim clear it prepared a rationale and chose the area (up to 900 square miles) between Killdeer and Val Marie, an area which it considered suitably unmodified by modern agriculture.

After making its request for a National Grasslands Park members of the Society wrote hundreds of letters. Sometimes the obstacles to the establishment of a park in this ranching area seemed impossible to overcome. Finally, in 1975, public hearings were held, but even though the hearing board recommended the establishment of a park, intergovernmental negotiations continued. Now, the federal government is slowly acquiring property and already it has forty or more square miles. However, there is still cattle-grazing in the area and the provincial government continues to hold the mineral rights. $\mathrm{H}$. Lorne Hansen, the Park Superintendent, has a Parks Canada office in Val Marie and invites anyone interested in grasslands to visit though at the moment the boundaries of the park have not yet been established. Indeed, the transition period may last for another five years and even then it may take several more years for the Master Plan to be developed.

To celebrate the Parks Centennial special events will be held this summer in Canadian National Parks. There will also be Parks Canada exhibits in prominent places in many Canadian cities. The Saskatchewan Natural History Society, in support of Parks Canada, is planning to hold its summer meeting in the Val Marie area during the weekend of June 7 - 9. Members hope 10 visit the prairie dog cairn located in the 


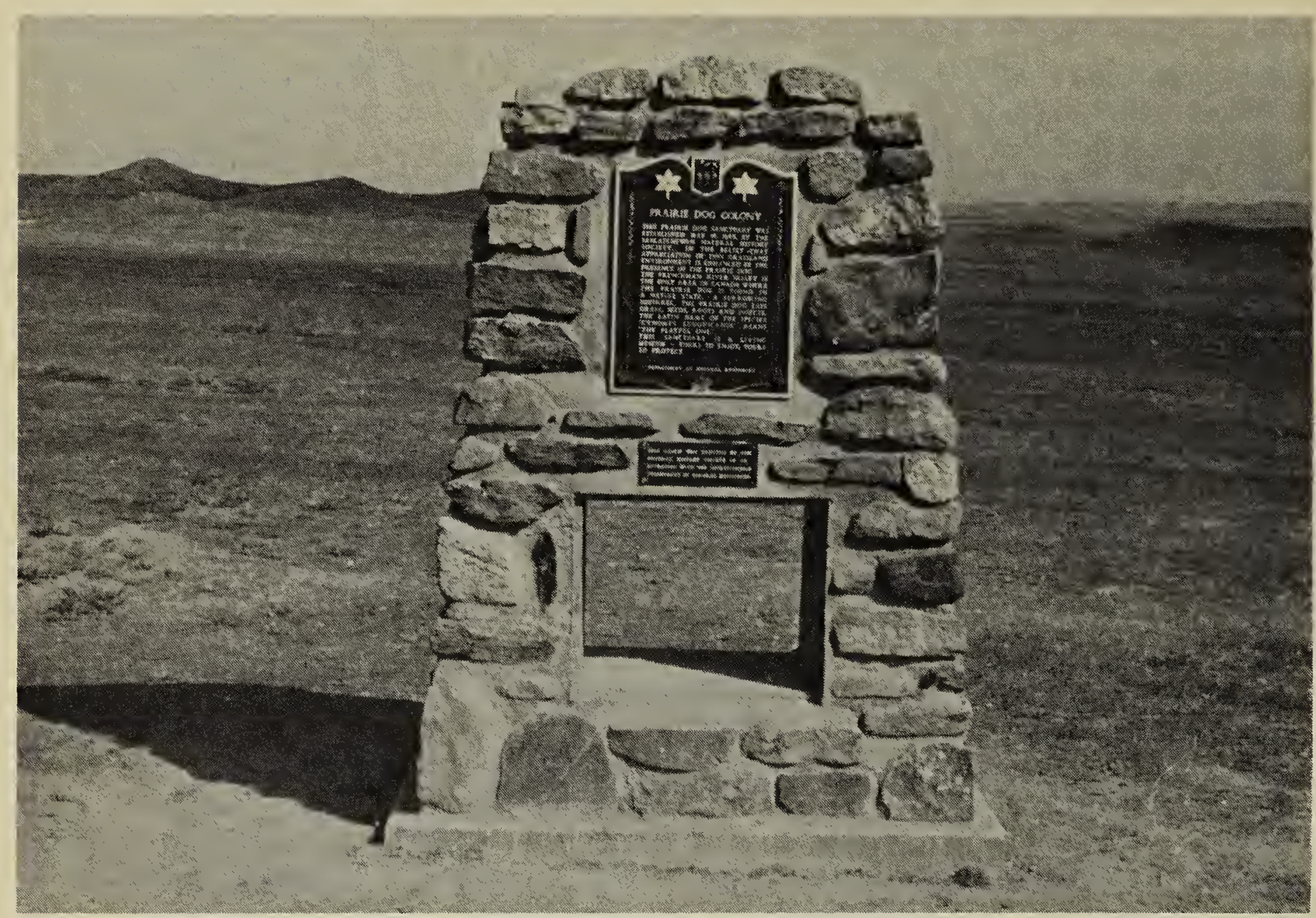

Stone cairn at Prairie Dog Colony near Val Marie

G.W. Seib

quarter section leased by the Society in 1964; they will also visit the rattlesnake hibernaculum, 70-mile butte and other interesting areas. Living ecosystems will interest naturalists primarily, but esthetic, cultural, archeological and paleontological sites will also appeal to many people.

It is reassuring to members of the Society to know that some of this important Canadian habitat will soon be preserved in a National Park. However, with the existence of ever-increasing world populations, National Parks in every country are under serious "people pressure." By establishing this park now and developing its Master Plan with knowledge of what is happening elsewhere, Parks Canada must include rules which will ensure that preservation has the highest priority. Rare plants and animals must be protected, for the whole ecosystem is fragile. And not only are biological sites important. Archeological, paleontological, cultural and aesthetic sites are also vulnerable.
As naturalists, we are optimistic that, when exploitation of natural resources in the area ends and the National Park is finally established, the preservation of native plants and animals will be the prime objective of the park. One problem, nevertheless, remains, the problem of the existence of exotic species which have been accidentally (or intentionally) introduced into the area by ranchers and farmers. All areas acquired by Parks Canada will have to be carefully examined for such exotic plants and animals. If these should prove to be aggressive species which will disrupt populations of native species, they must be controlled or, preferably, eliminated.

Another problem relates further to the aforementioned "people pressure." It would be unreasonable to give up the agricultural use of the area only to allow overuse by tourists, campers and recreationists. Big national parks try to solve the use-versus-preservation conflict by zoning 
parks. This park will not be large enough for such a compromise. There must, therefore, be strict control of access to the more fragile parts of the park. Disruptive activities such as camping, horse-back riding, etc. which may be associated with the park can be developed either in the buffer zone surrounding the park or in adjacent towns.
The Society is grateful for the recognition accorded to it by Parks Canada and the people of Canada. In return, the Society promises to continue to work for the development of a National Grasslands Park which will be consistent with its aim to preserve all aspects of our Canadian heritage.

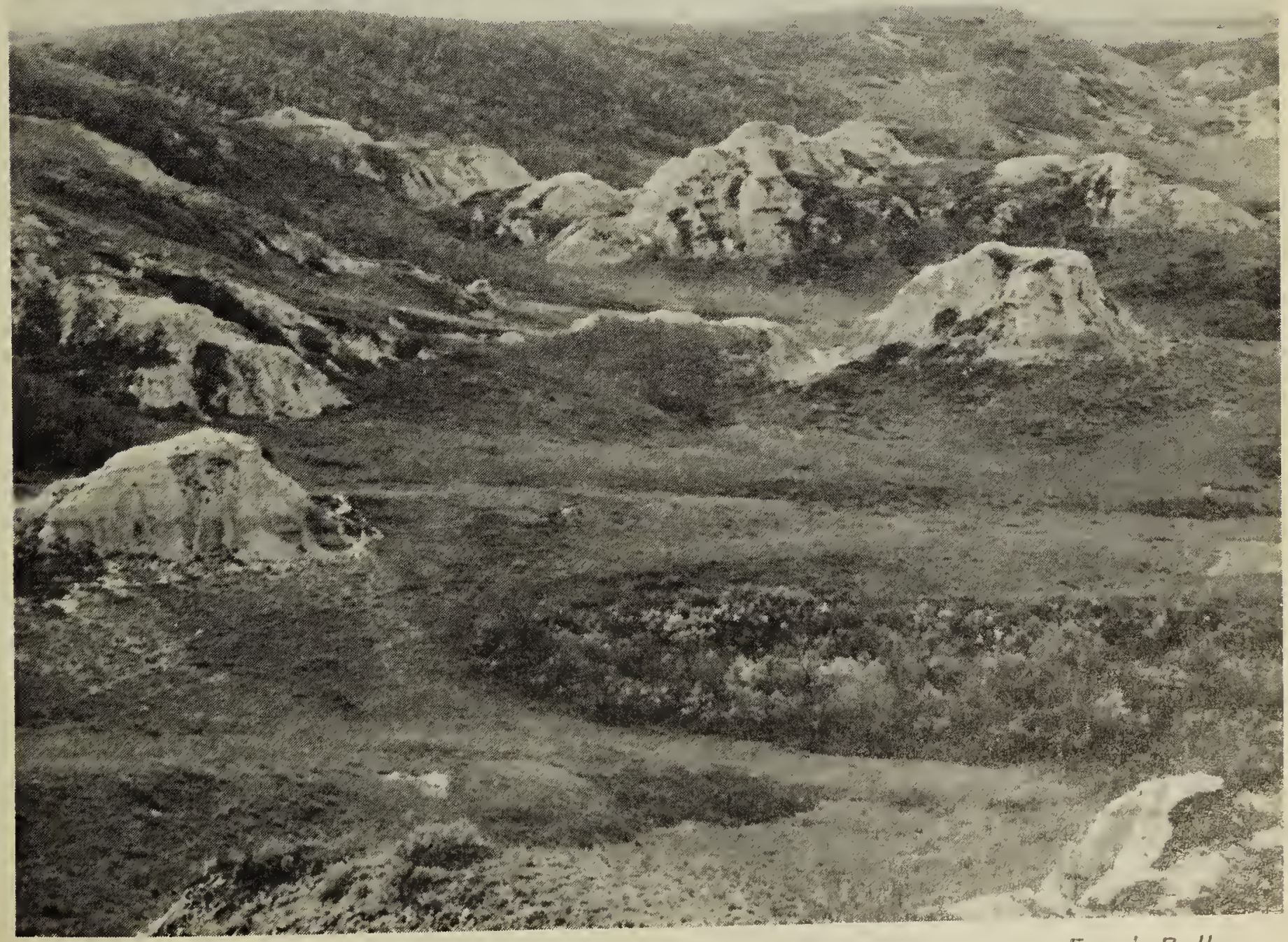

